\title{
Durability Based Service Life Estimation for Chloride Exposed Cracked and Self-Healed Concrete
}

\author{
Nele De Belie ${ }^{1}$, Bjorn Van Belleghem ${ }^{1}$, Sylvia Keßler ${ }^{2}$, Philip Van den Heede ${ }^{1}$ and Kim \\ Van Tittelboom ${ }^{1}$ \\ ${ }^{1}$ Magnel-Vandepitte Laboratory for Structural Engineering and Building Materials, Ghent University, \\ Technologiepark Zwijnaarde 60, B-9052 Ghent, Belgium, nele.debelie@ugent.be \\ ${ }^{2}$ Helmut-Schmidt-University, Chair of Engineering Materials and Building Preservation, \\ Holstenhofweg 85, Hamburg, 22043, Germany, sylvia.kessler@hsu-hh.de
}

\begin{abstract}
Chloride ingress in cracked concrete leads to rapid corrosion of embedded steel reinforcement and a decrease of the expected service life. Corrosion monitoring experiments showed that a $300 \mu \mathrm{m}$ wide crack caused initiation of corrosion of a rebar $(\varnothing 10 \mathrm{~mm})$ with a concrete cover of $26 \mathrm{~mm}$ within three weeks of cyclic exposure to a $33 \mathrm{~g} / \mathrm{l} \mathrm{NaCl}$ solution. After a period of unstable corrosion activity during the first 20 weeks of exposure, corrosion propagated further at a relatively high rate ( 0.345 to $0.718 \mathrm{~mm}^{3} /$ week). Application of a theoretical pitting model revealed that a reduction of about $50 \%$ of the rebar cross-section would occur after a period of 9 to 20 years of continuous cyclic exposure to chlorides. To avoid such rapid degradation, the use of self-healing concrete can be proposed. Introduction of macro-encapsulated polyurethane into the concrete matrix, will lead to the formation of a (partial) barrier against ingress of chlorides at the moment cracks appear. Corrosion monitoring experiments showed that the autonomous crack healing could not always prevent corrosion initiation, but caused an important reduction of the corrosion rate during the 44 weeks exposure period. The mean rate of volumetric loss of steel amounted to $0.042 \mathrm{~mm}^{3} /$ week, about 15 times lower than for the untreated cracked samples. The rebars also showed no or very limited signs of corrosion after visual inspection. The simplified pitting model indicated that a 50\% reduction in steel cross-section would take more than 5 times longer for samples with self-healing properties versus ordinary cracked samples.
\end{abstract}

Keywords: Steel Corrosion, Durability, Cracking, Self-Healing Concrete, Service Life Prediction.

\section{Introduction}

\subsection{General Introduction}

Reinforced concrete is without doubt one of the most ingenious inventions in the construction industry. By combining concrete with steel, a composite material is created which has both a high compressive and tensile strength. Numerous structures, such as buildings, bridges, tunnels and roads have been made using reinforced concrete due to its high strength and high degree of freedom in shape and design. A huge amount of steel reinforced concrete structures were built by the mid- $20^{\text {th }}$ century. However, these structures are now over 50 years old and several have shown major deterioration. One very common problem in reinforced concrete structures is the appearance of cracks when the concrete element is subjected to tensile stresses. These cracks form preferential pathways for chlorides or carbon dioxide to penetrate the concrete and rapidly reach the steel reinforcement. This will increase the risk for initiation and possibly further propagation of steel reinforcement corrosion. Several studies have provided proof of a 
shortening of the corrosion initiation period due to the presence of cracks and chlorides (Ahmadi et al., 2015; Jaffer and Hansson, 2008; B. Otieno et al., 2010; Sangoju et al., 2011). In some cases corrosion onset is almost instantaneous after crack appearance (Schieß1 \& Raupach, 1997). Moreover, once corrosion has initiated, there can be an acceleration of the corrosion rate in the propagation phase as the crack provides easier supply of chlorides, moisture and oxygen to the reinforcement (Ahmadi et al., 2015; Li et al., 2017; Otieno et al., 2010; Schieß1 and Raupach, 1997). Mostly, an increase in the corrosion rate was found in short term tests ( $<$ two years) while less influence of cracks on the propagation rate was found in long-term studies (Käthler et al., 2017).

Thus, cracks should be repaired as soon as possible to avoid major durability issues. However, cracks in certain structures can be invisible or inaccessible, impairing repair works. Moreover, repair works have a big economic impact due to the (in)direct costs involved. Therefore, the idea of providing the concrete with the ability of restoring cracks by itself without any human interference grew during the last few decades. One promising approach to create a so-called self-healing concrete consists of the embedment of encapsulated healing agents in the concrete matrix. Brittle macro-capsules are placed in regions subjected to high tensile stresses and where cracks would cross the steel reinforcement.

In this research, autonomous crack healing through the use of encapsulated healing agents was investigated for its efficiency to reduce the ingress of chlorides into the concrete matrix and to improve the corrosion resistance of reinforced concrete.
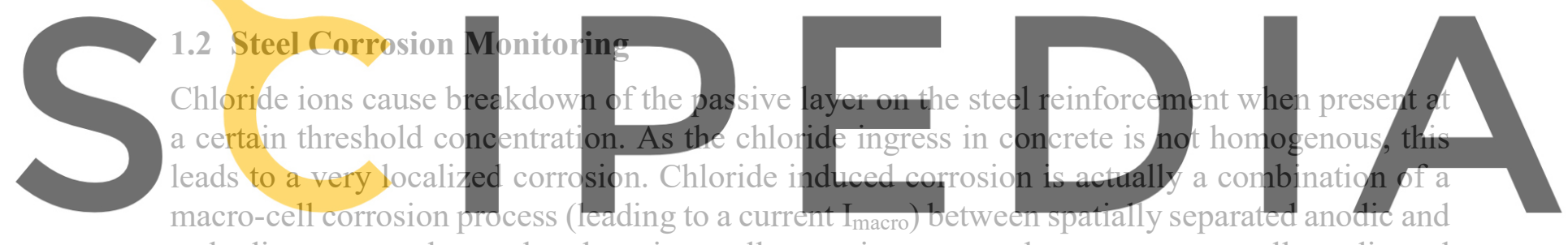
cathodic areas on the steel and a micro-cell corrosion process between very small anodic and

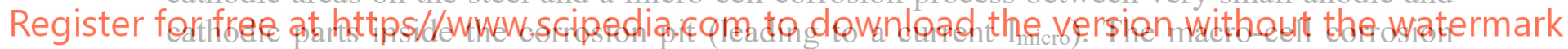
process will usually lead to much higher corrosion rates (Schieß1 and Raupach, 1997). According to Ohm's law, the current which is flowing between anodic and cathodic sites on the steel surface is directly proportional to the potential difference between those areas and inversely proportional to the resistances of the system. On this basis, the macro-cell corrosion process can be represented by an equivalent electric circuit.

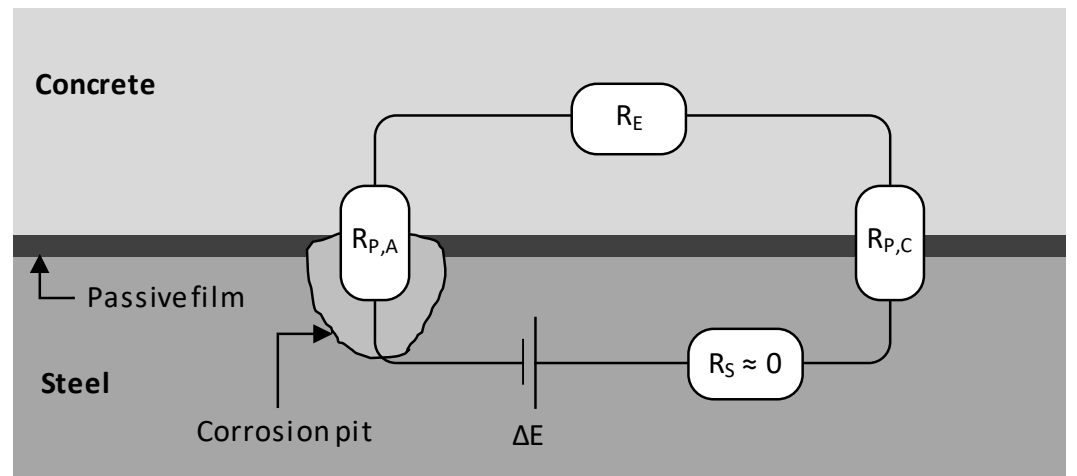

Figure 1. Equivalent circuit model for macro-cell corrosion, redrafted after Hiemer et al. (2015). 
As can be seen from Figure 1, the equivalent circuit consists of four resistances: the resistance of the anodic partial reaction $\left(\mathrm{R}_{\mathrm{P}, \mathrm{A}}\right)$, the resistance of the cathodic partial reaction $\left(R_{P, C}\right)$, the resistance of the concrete $\left(R_{E}\right)$ and the resistance of the steel $\left(R_{S}\right.$, which is assumed to be zero). The potential difference $\Delta \mathrm{E}$ (driving potential) between the anode and the cathode can be seen as the driving force for the corrosion process. In order to estimate the rate of corrosion, the total corrosion current ( $\left.\mathrm{I}_{\text {corr }}\right)$ should be calculated, as in Equation (1).

$$
\mathrm{I}_{\text {corr }}=\mathrm{I}_{\text {macro }}+\mathrm{I}_{\text {micro }}=\frac{\Delta \mathrm{E}}{\mathrm{R}_{\mathrm{P}, \mathrm{A}}+\mathrm{R}_{\mathrm{P}, \mathrm{C}}+\mathrm{R}_{\mathrm{E}}}+\mathrm{I}_{\text {micro }}
$$

\section{Materials and Methods}

\subsection{Concrete Samples}

\section{A reference concrete as described in Van den Heede (2014) was used as a representative mixture for concrete in exposure class XS2, i.e. submerged reinforced concrete in contact with chlorides from seawater (Table 1). The mixture had a water-to-binder ratio of 0.41 and a fly ash-to-binder ratio of $15 \%$, according to the k-value concept (NBN B15-001, 2004). The concrete had a slump class S4 and a compressive strength at 28 days of $65.2 \pm 2.0 \mathrm{MPa}$.}
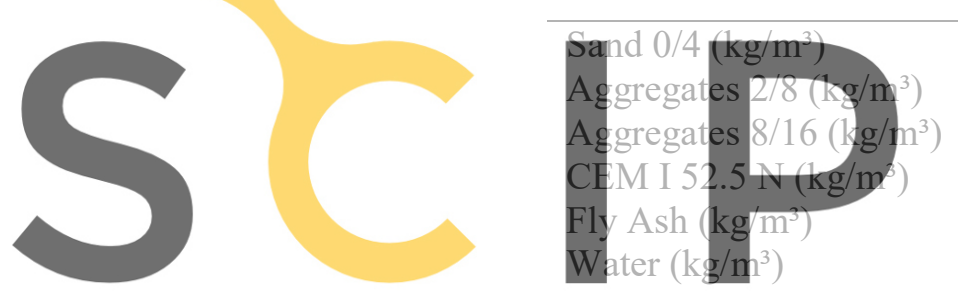

Superplasticizer ( $\mathrm{ml} / \mathrm{kg}$ binder)

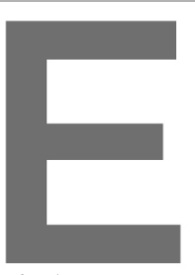

dsoints

made for corrosion $m$

on Hiemer et al. (2015) and Ke

(Van Belleghem et al., 2018). The steel reinforcement (BE500S) in the concrete prisms consisted of an anodic and a cathodic part which were electrically separated from each other. The anode was a central steel bar $(\varnothing=10 \mathrm{~mm}, \mathrm{~L}=250 \mathrm{~mm})$, partially coated with cement paste and epoxy resin to prevent crevice corrosion, with only the central $50 \mathrm{~mm}$ exposed. The cathode consisted of two electrically connected cages (each with four longitudinal rebars $\varnothing=8 \mathrm{~mm}$ and five stirrups $\varnothing=6 \mathrm{~mm}$ which were welded to each other). The anode/cathode ratio was kept small $(1 / 58)$ to accurately measure the macro-cell corrosion process. Both parts were connected to the exterior by means of an insulated copper wire. In addition, two glass fiber reinforced polymer rebars $(\varnothing=6 \mathrm{~mm})$ were placed in the compression zone. Four types of specimens were prepared (with 3 replicates): uncracked specimens (UNCR), cracked but not healed specimens (CR), and self-healing specimens containing two layers of 6 capsules filled with high (6700 mPas) or low (200 mPas) viscosity polyurethane (PU_HV_CAPS and PU_LV_CAPS). The samples contained an $\mathrm{Ag} / \mathrm{AgCl}$ internal reference electrode, fixed to the coated part of the anodic rebar. After casting, the prisms were stored at $20^{\circ} \mathrm{C}$ and a relative humidity above $95 \%$. 
The prisms were demolded after 24 hours and stored at the same conditions until 28 days. Then, anode and cathode were connected to each other through the external copper wires.
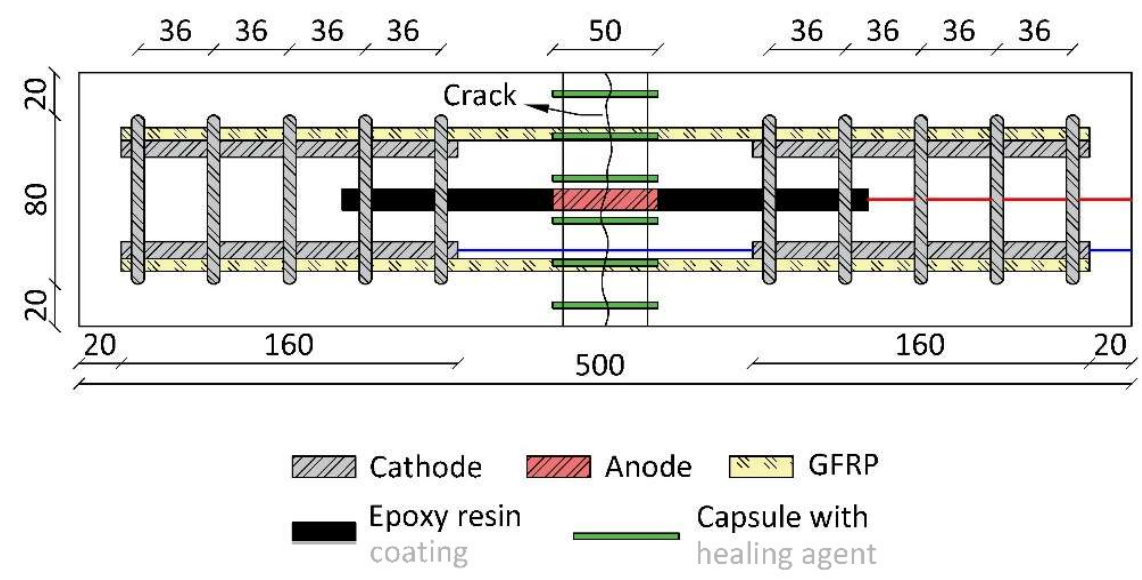

Figure 1. Reinforcement scheme and capsule positions in the concrete prisms (dimensions in mm) - top view, redrafted after Van Belleghem et al. (2018).

\subsection{Crack Creation}

At 28 days, a flexural crack with a target width of $300 \mu \mathrm{m}$ was created in the concrete prisms by means of a three-point bending test. The concrete prisms contained a triangular notch with a height of $3.5 \mathrm{~mm}$ at mid-span and consequently crossed of a special frame (Figure 2). After crack relative humidity of $60 \%$ for 48 hours to allow the polyurethane

\subsection{Exposure Regime}
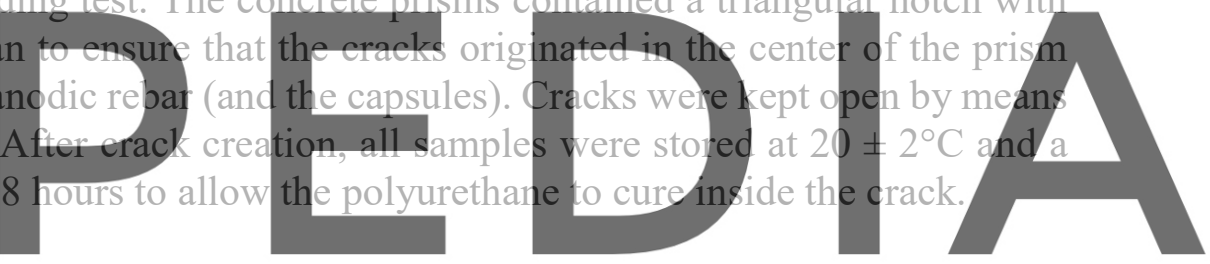

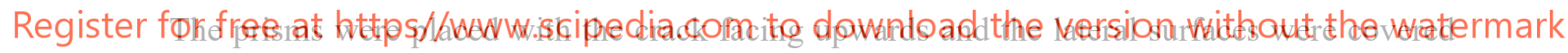

with aluminum butyl tape, extending beyond the upper surface of the samples, to create a basin with three compartments (Figure 2). The top (cracked) surface of the samples was exposed weekly to $1 \mathrm{~d}$ wetting and $6 \mathrm{~d}$ drying cycles for a total duration of 44 weeks. During the wet period, the central compartment was filled with a $33 \mathrm{~g} / 1 \mathrm{NaCl}$ solution, while the outer compartments were filled with a $1.15 \mathrm{~g} / \mathrm{l} \mathrm{Ca}(\mathrm{OH})_{2}$ solution.
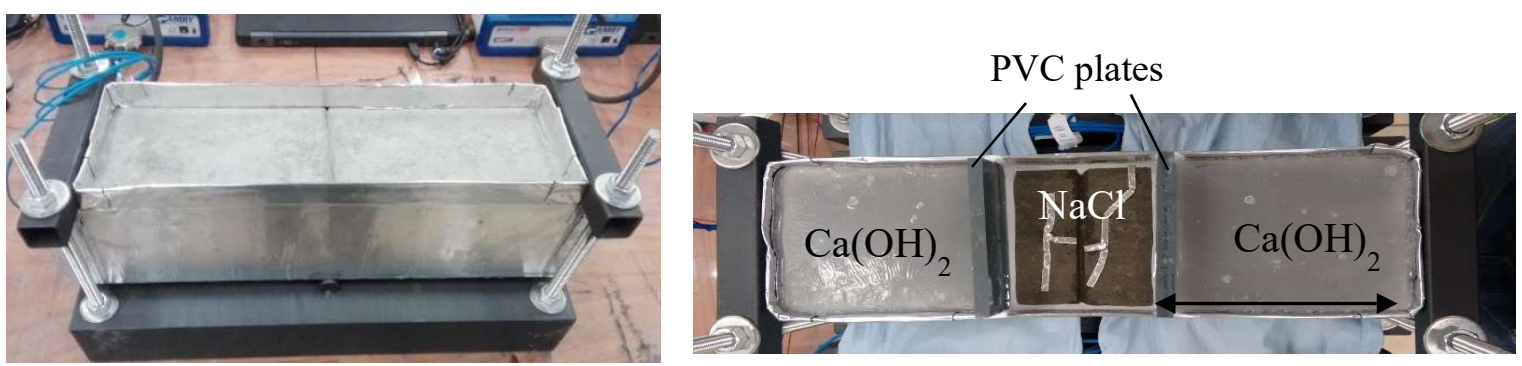

Figure 2. Concrete prism mounted in a three-point bending test frame (left); Basins on the surface (right). 


\subsection{Corrosion Measurements}

The macro-cell corrosion current between anode and cathode ( $\left.\mathrm{I}_{\text {macro }}\right)$ was measured once every hour with a low resistance ammeter. Electrochemical measurements were performed at the end of the wet period with a potentiostat using the internal $\mathrm{Ag} / \mathrm{AgCl}$ reference electrode (SAE). The corrosion potential $\left(\mathrm{E}_{\text {corr }}\right)$ was measured while anode and cathode were connected. Other parameters were measured as well (for results see Van Belleghem, 2018), such as open circuit potential (OCP) of anode and cathode, linear anodic and cathodic polarization resistance $\left(\mathrm{R}_{\mathrm{P}, \mathrm{A}}\right.$ and $\left.\mathrm{R}_{\mathrm{P}, \mathrm{C}}\right)$, and concrete resistance $\left(\mathrm{R}_{\mathrm{E}}\right)$. All electrochemical measurements were performed weekly during the first 12 weeks of the wet-dry cycles and thereafter every two to four weeks.

\subsection{Chloride Profiling and Visual Evaluation}

After the corrosion monitoring period, the chloride ingress was determined by means of chloride profile grinding (layers of $4 \mathrm{~mm}$ thickness) in an area of $10 \mathrm{~mm} \times 30 \mathrm{~mm}$ around the crack next to the location of the anodic rebar. The total chloride content of each powder was determined by means of acid-soluble chloride extraction in a nitric acid solution followed by a potentiometric titration against silver nitrate. After determination of the chloride profiles, the anodic steel reinforcement bars were removed from the concrete prisms for visual inspection of the corrosion products. Next, all rebars were immersed in a chemical cleaner solution ( $\mathrm{HCl}: \mathrm{H}_{2} \mathrm{O}=1: 1+3 \mathrm{~g} / 1$ urotropine) for 24 hours in order to remove all corrosion products and residual concrete. Afterwards, the steel rebars were visually inspected again to investigate the
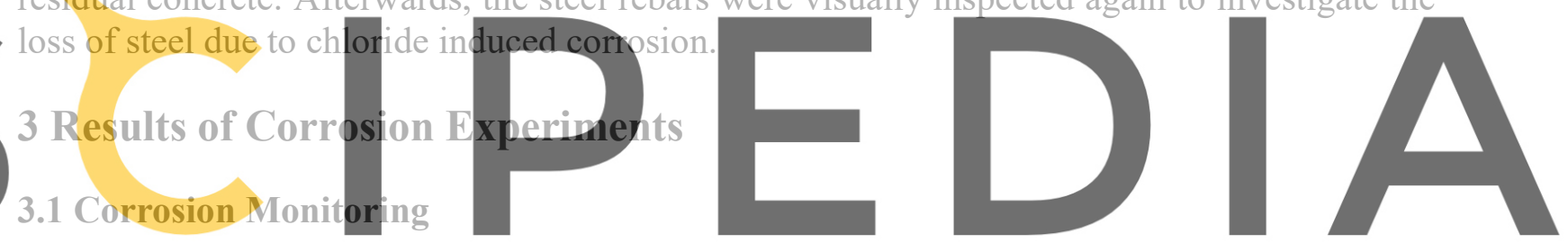

An overview of the measured electrochemical parameters during the 50 weeks monitoring

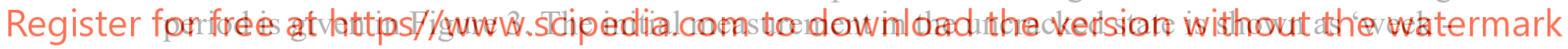

1', while 'week 0' represents the values after cracking but without exposure to a solution. From week 1 until week 44 the samples were exposed to the wet-dry cycles. The last measurement at week 50 was performed after a six week dry period.

The uncracked samples showed a non-active state of corrosion along the whole exposure period. No macro-cell corrosion current was detected and the corrosion potential was nearly constant at values of -70 to $+80 \mathrm{mV}$ SAE. The cracked samples showed clear evidence of corrosion initiation within the first three weeks of exposure to $33 \mathrm{~g} / \mathrm{l} \mathrm{NaCl}$ solution: there is a steep rise in the macrocell corrosion current and a concurrent drop of the corrosion potential down to values between -200 and $-400 \mathrm{mV}$ SAE. Every week a sharp increase of the macro-cell corrosion current can be seen for all the cracked samples, which corresponds to the start of each wet period. Apart from the occurrence of these peaks, the overall macro-cell corrosion current shows a decreasing trend during the first twenty weeks of exposure. It remains relatively constant in the period from 20 to 44 weeks in a range of 20 to $60 \mu \mathrm{A}$, which shows that the corrosion is propagating at a constant rate. The corrosion parameters measured at week 50 , after a dry period of six weeks, indicate that the corrosion is propagating at a lower rate. This is logical as the continuous supply of chlorides and moisture act as catalysts for the anodic and cathodic corrosion reaction. 
Generally, the corrosion behaviour of the self-healing samples with high viscosity PU (PU_HV_CAPS) was very similar to the corrosion behaviour of the cracked samples. However, the self-healing samples with low viscosity PU (PU_LV_CAPS) behaved more closely to the uncracked samples. The macro-cell corrosion current was negligible and the driving potential was comparable to the values found for the uncracked samples.
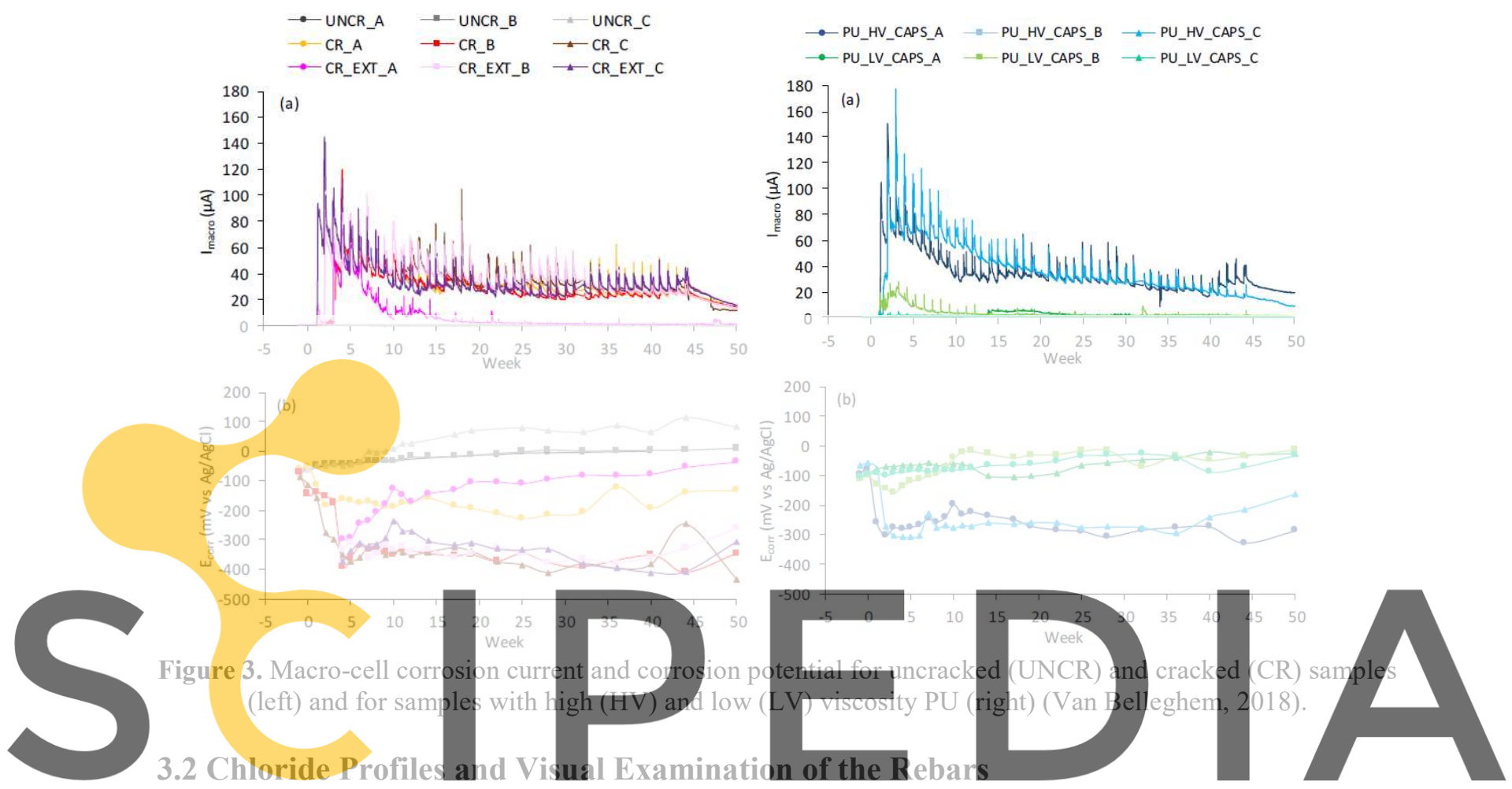

The obtained chloride profiles are shown in Figure 4 together with the location of the rebar. For

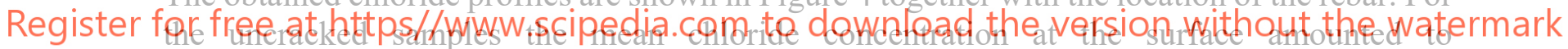

$3.43 \pm 0.05 \mathrm{~m} \% / b i n d e r$ and then dropped fast to nearly zero at a depth of $18 \mathrm{~mm}$ into the

concrete matrix. The samples containing an untreated crack showed a very high chloride concentration close to the surface of the samples (up to $6 \mathrm{~m} \% / \mathrm{binder}$ ). The chloride concentration drops steeply when going to the second layer (4-8 $\mathrm{mm}$ below the surface) and gradually decreases until a depth of 20-25 mm. At depths larger than $20 \mathrm{~mm}$, the chloride concentration remained almost constant at about 1.3 to $1.5 \mathrm{~m} \% /$ binder. Autonomous crack healing with low viscosity polyurethane (PU_LV_CAPS) led to a clear reduction of the chloride concentration compared to the cracked samples. At the level of the reinforcement the chloride concentration was about $0.26 \mathrm{~m} \% /$ binder, which was three to seven times lower compared to the concentration found at the level of the reinforcement of the cracked samples.

Visual examination of the rebars from the uncracked samples showed no corrosion products and no visual damage to the rebars was observed after cleaning. For the cracked samples, clear formation of corrosion products on the central part of the anodic rebar was noticed. After cleaning, clear pitting corrosion was observed at the same location. The series PU_LV_CAPS showed negligible formation of corrosion products and no pitting corrosion. 

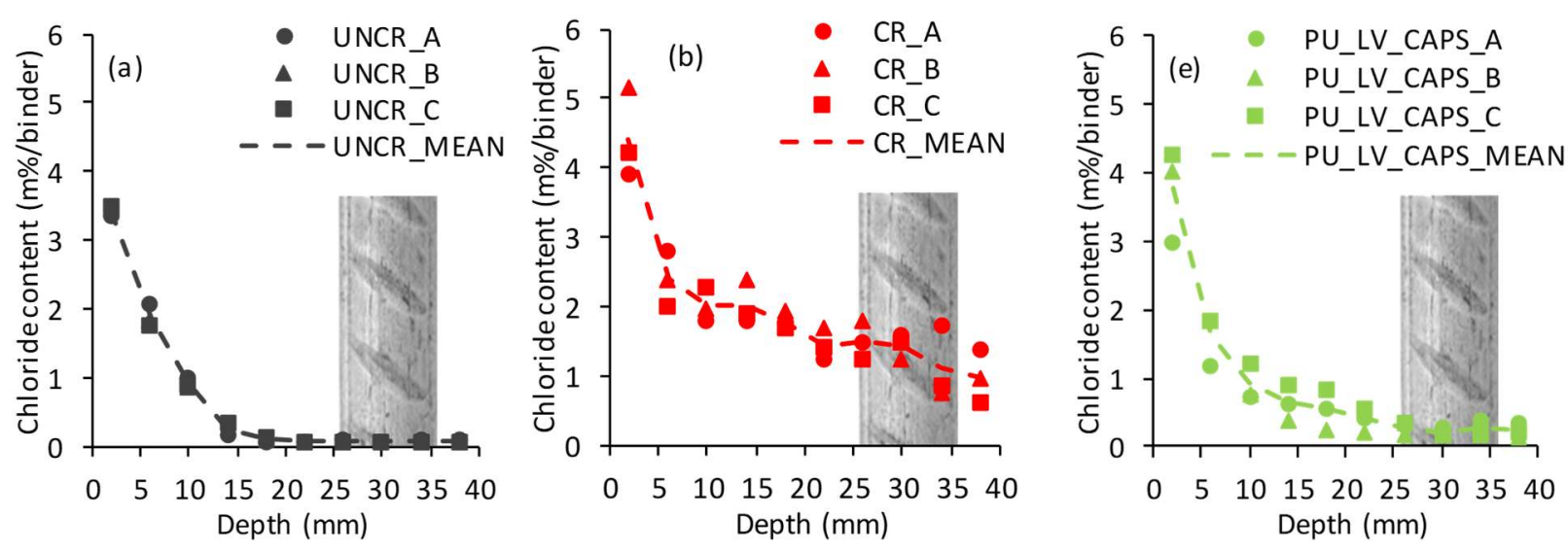

Figure 4. Chloride profiles of all sample series with indication of rebar location.

\section{Prediction of Reduction of Steel Cross-Section}

The mass loss of steel due to the macro-cell corrosion reaction can be determined theoretically from the measurement of the macro-cell corrosion current in time using Faraday's law according to Equation (2):

$$
\mathrm{m}=\frac{\mathrm{Q}}{\mathrm{F}} \cdot \frac{\mathrm{M}}{\mathrm{Z}}
$$

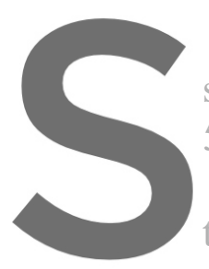

where $m$ is the mass substance $(\mathrm{C}), \mathrm{F}$ is the $55.845 \mathrm{~g} / \mathrm{mol}$ ) and $\mathrm{z}$ is t The total charge pass time. The mass loss due to micr
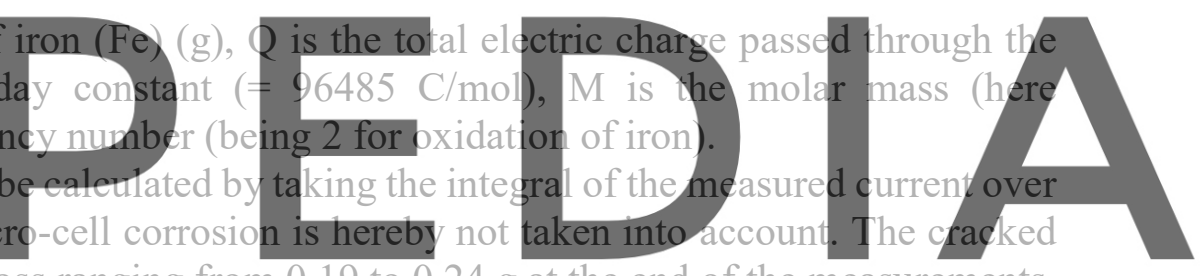
samples showed a large mass loss ranging from 0.19 to $0.24 \mathrm{~g}$ at the end of the measurements. Register for firther aprediction can be made by calculating the volyme loss in. the initial 20 weeks af ermark exposure (high and unstable corrosion current, leading to a volume loss of 6.36 to $15.45 \mathrm{~mm}^{3}$ ) and adding this to the volume loss in the secondary period, where a relatively stable macro-cell corrosion current develops ( 0.551 to $\left.0.718 \mathrm{~mm}^{3} / \mathrm{week}\right)$. A similar calculation for the selfhealing prisms with LV PU, resulted in an initial volume loss of 1.65 to $10.34 \mathrm{~mm}^{3}$ and a rate of volumetric loss of $0.042 \mathrm{~mm}^{3} /$ week afterwards (14 times lower than what was found for the untreated cracked samples).

Application of a simplified pitting model proposed in Van Belleghem (2018) revealed that, for a steel bar with a diameter of $10 \mathrm{~mm}$ in cracked concrete, a reduction of about $50 \%$ of the cross-section would occur after a period of 9 to 20 years of continuous cyclic exposure to chlorides. However, for the self-healing concrete with LV PU, such a 50\% reduction would take more than 100 years to occur.

\section{Conclusions}

- Cracks in concrete allow rapid penetration of chlorides and impair the durability of the structure. Within three weeks of cyclic exposure to a $33 \mathrm{~g} / \mathrm{l} \mathrm{NaCl}$ solution, the reinforcement in lab specimens with a $300 \mu \mathrm{m}$ wide crack started to corrode. A volume loss of 6.36 to $15.45 \mathrm{~mm}^{3}$ was calculated for the initial 20 weeks of exposure, followed by a period of 
relatively stable macro-cell corrosion current leading to a volume loss of 0.55 to $0.72 \mathrm{~mm}^{3} /$ week. This means that $50 \%$ of the rebar cross-section (diameter $10 \mathrm{~mm}$ ) would be lost after 9 to 20 years. Uncracked samples showed a non-active state of corrosion during the whole exposure period of 44 weeks.

- In the case of self-healing concrete with macro-encapsulated polyurethane, crack formation led to rupture of the capsules and release of healing agent in the crack. Low viscosity polyurethane induced a decrease of the corrosion rate in comparison to cracked and untreated samples. After an initial volume loss of $1.65-10.34 \mathrm{~mm}^{3}$, the mean steel loss rate amounted to $0.042 \mathrm{~mm}^{3} /$ week only. At the end of the experiment the rebars showed no or very limited signs of corrosion. A $50 \%$ reduction in steel cross-section was estimated to take more than 100 years, using a simplified pitting model.

\section{Acknowledgements}

This research was performed in the framework of ISHECO (Impact of Self-Healing Engineered Materials on steel COrrosion of reinforced concrete) - program SHE (Engineered Self-Healing materials) and funded by SIM and VLAIO. Philip Van den Heede is postdoctoral fellow of Research Foundation - Flanders (FWO) (project No. 3E013917)

\section{ORCID}

Nele De Belie: http://orcid.org/0000-0002-0851-6242; Bjorn Van Belleghem: https://orcid.org/0000-0003-12941724; Sylvia Kessler: http://orcid.org/0000-0002-1335-1104; Philip Van den Heede: https://orcid.org/0000-00031307-2831; Kim Van Tittelboom: https://orcid.org/0000-0002-7718-3189

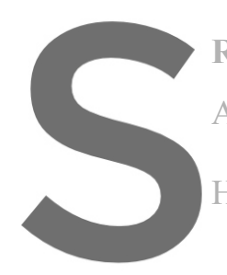

References
Ahmadi, B., Ramezanianpou
harsh marine environment
Hiemer, F., Keßler, S. and
time chloride exposure. In and Retrofitting (pp. 99-106). Leipzig, Germany.
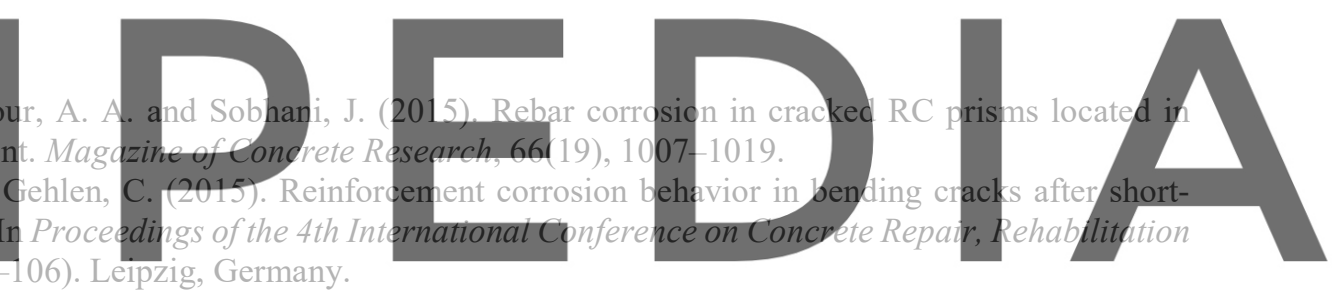

Jaffer, S. J. and Hansson, C. M. (2008). The influence of cracks on chloride-induced corrosion of steel in ordinary

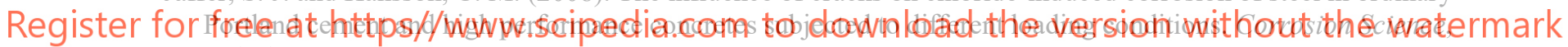
50(12), 3343-3355.

Käthler, C. B., Angst, U., Wagner, M., Larsen, C. K. and Elsener, B. (2017). Effect of cracks on chloride-induced corrosion of reinforcing steel in concrete - a review. Norwegian Public Roads Administration, Report 454.

Keßler, S., Hiemer, F. and Gehlen, C. (2017). Einfluss einer Betonbeschichtung auf die Mechanismen der Bewehrungskorrosion in gerissenem Stahlbeton. Beton- Und Stahlbetonbau, 112(4), 198-206.

Li, W., Liu, W. and Wang, S. (2017). The effect of crack width on chloride-induced corrosion of steel in concrete. Advances in Materials Science and Engineering, Article ID 3968578, 11 pages.

Otieno, M.B., Alexander, M.G. and Beushausen, H. (2010). Corrosion in cracked and uncracked concrete: influence of crack width, concrete quality and crack reopening. Magazine of Concrete Research, 62(6), 393404.

Sangoju, B., Gettu, R., Bharatkumar, B. H. and Neelamegam, M. (2011). Chloride-Induced Corrosion of Steel in Cracked OPC and PPC Concretes: Experimental Study. Journal of Materials in Civil Engineering, 23(7), 1057-1066.

Schieß1, P. and Raupach, M. (1997). Laboratory studies and calculations on the influence of crack width on chloride-induced corrosion of steel in concrete. ACI Materials Journal, 94(1), 56-61.

Van Belleghem, B. (2018). Effect of Capsule-Based Self-Healing on Chloride Induced Corrosion of Reinforced Concrete. $\mathrm{PhD}$ thesis, Ghent university.

Van Belleghem, B., Kessler, S., Van den Heede, P., Van Tittelboom, K. and De Belie, N. (2018). Chloride induced reinforcement corrosion behavior in self-healing concrete with encapsulated polyurethane. Cement and concrete research, 113, 130-139. 